\title{
JOEL SHERZER
}

\section{CEREMONIELLE DIALOGISKE HILSNER BLANDT KUNA- INDIANERNE I PANAMA}

I sit fascinerende og banebrydende komparative studie af ceremoniel dialog i Sydamerikas tropiske lavland medtager Niels Fock kunaindianerne i Panama (Fock 1963; for nyere oversigter, se Sherzer 1983; Urban 1986). Kunaerne, hvis sprog tilhører chibchanfamilien, er den nordligste gruppe i Focks oversigt. Denne oversigt, bemærkelsesværdigt bred som den var, synes nu at kunne udvides til også at omfatte såvel nogle mayagrupper længere nordpå (Burns 1980) som andre oprindelige grupper i Central- og Sydamerika. Faktisk er dialogisk tale, og specielt ceremoniel dialog, en fast del af de indfødte latinamerikanske folks kulturelle arv (se Sherzer \& Urban 1986; Sammons \& Sherzer under udgivelse).

\section{Kunas ceremonielle dialog}

Kunaernes ceremonielle dialog ses i sin mest ritualiserede form i høvdingenes sang i landsbyens forsamlingshus. Dette er den form, hvori myte, historie og personlige oplevelser fremføres for kunasamfundet i et rituelt og metaforisk sprog. To høvdinge sidder overskrævs i hængekøjer ved siden af hinanden i centrum af forsamlingshuset, mens den ene synger til den anden, svareren, som bekræfter, at ,sådan er det“ efter hvert vers (se Sherzer 1983, 1990). Høvdingene er omgivet af et publikum af mænd og kvinder. Gennem hele sangen holder høvdingene deres arme stift ned langs kroppen; de stirrer ud i rummet og ændrer ikke ansigtsudtryk. Efter sangen rejser en af høvdingenes talsmænd sig op, og i en formel stil, der dog er lettere forståelig for almindelige kunaer, end høvdingenes sang er, omformulerer og fortolker han sangen for publikum.

Den rituelle hilsen mellem to høvdinge fra forskellige landsbyer, arkan kae (ordret „gribe hænder", selv om det at udveksle håndtryk er relativt sjældent blandt kunaerne) fremføres også som en sunget ceremoniel dialog, om end der her ikke er nogen efterfølgende talt fortolkning og ej heller noget officielt publikum. Netop arkan kae, om hvilken der ikke tidligere er offentliggjort nogen publikationer, er emnet for denne artikel.

Kunaernes ceremonielle dialog, heri medregnet arkan kae, er en rituel menneske-tilmenneske-kommunikation. Hermed står den i kontrast til det andet væsentlige verbale ritual hos kunaerne, nemlig det som bruges i forbindelse med magi og helbredelse. Hel- 
bredelsesritualer fremføres af et enkelt menneske for en eller flere usynlige repræsentanter for åndeverdenen (en fysisk manifestation af disse ånder kan være til stede i form af menneskelignende trædukker eller en lang fløjte). Selv om denne menneske-til-åndkommunikation ikke umiddelbart ligner den ceremonielle menneske-til-menneske-dia$\log$, er der, ifølge såvel kunaernes tro som den faktiske praksis, tale om en dialog. Dette fremgår klart af de verbale tekster, som også omfatter citerede dialoger mellem ånder og mennesker og mellem ånder. ${ }^{1}$

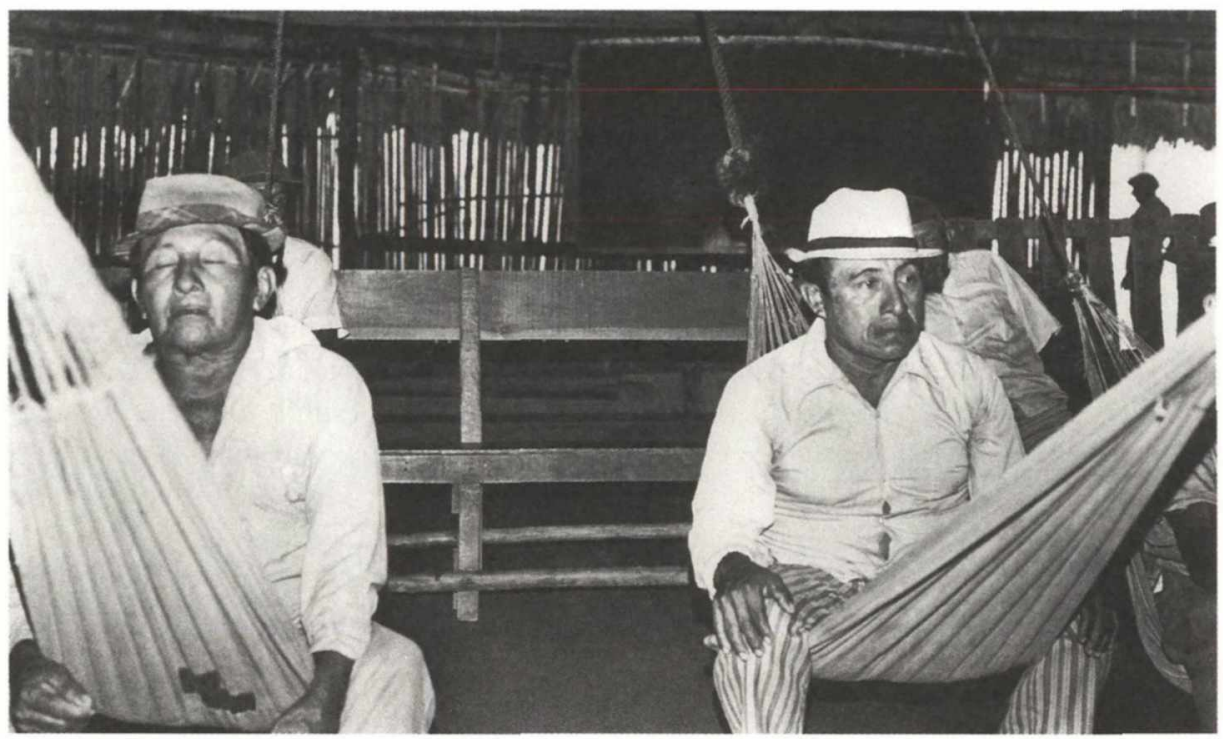

Foto af forfatteren

\section{Arkan kae: Rituel hilsen}

Arkan kae fremføres ved en høvdings ankomst fra en anden landsby, mellem den bes $\varnothing-$ gende og en af værtslandsbyens høvdinge, eller, især når der er flere bes $\varnothing$ gende fra flere forskellige øer, om morgenen, når høvdingene vågner. I det sidste tilfælde fremfører adskillige høvdingepar overlappende og samtidige hilsner. En bes $ø$ gende høvdings ankomst er en særlig begivenhed, og når en høvding ankommer fra en anden landsby, hejser man på øen Mulatuppu Panamas flag i en flagstang foran forsamlingshuset. Der bliver det under hans bes $\varnothing \mathrm{g}$. Ved ankomsten stiler høvdingen og hans følge, der typisk består af hans kone, hans talsmand og en af hans politibetjente, direkte mod forsamlingshuset. Derfra ledes de af en Mulatuppu-politibetjent til en eller andens hus, hvor de bader for at vaske saltvandet af sig. Derefter vender de tilbage til forsamlingshuset, hvor den bes $\emptyset$ gende høvding og en af hans værtshøvdinge fremfører arkan kae. Arkan kae tager, som al sang i forsamlingshuset, form af en ceremoniel dialog mellem to høvdinge, men udmærker sig ved, at de to høvdinge skiftes til at synge. Først synger den besøgende høvding og hans vært fungerer som svarer. Derefter bytter de, så værtshøvdingen synger, og den besøgende høvding svarer. Siden byttes rollerne en eller to gange mere. Folk, som sidder rundt om, taler stilfærdigt sammen indbyrdes, mens de lytter til fremførelsen af arkan kae. Under denne begivenhed serverer kvinder fra værtslandsbyen forskellige drikke 
som kaffe, kakao, Kool-Aid og saft af sød majs for de besøgende og andre tilstedeværende. Disse forfriskninger sendes rundt til såvel de syngende som tilskuerne og udgør indledningen til de særlige drikke- og spisemønstre, som vil kendetegne høvdingens og hans følges besøg. Når arkan kae er afsluttet, går den besøgende høvding og hans følge ud for at bade og spise i en vens eller en tildelt værts hjem.

Sproget i arkan kae er i lighed med sproget i den mere generelle ceremonielle kunadialog rituelt, esoterisk, metaforisk og poetisk. Med hensyn til indholdet handler arkan kae om høvdingenes og deres landsbyers helbred, deres rejser og deres oplevelser. For at illustrere arkan kae præsenteres en afskrift af et konkret eksempel sidst i denne artikel.

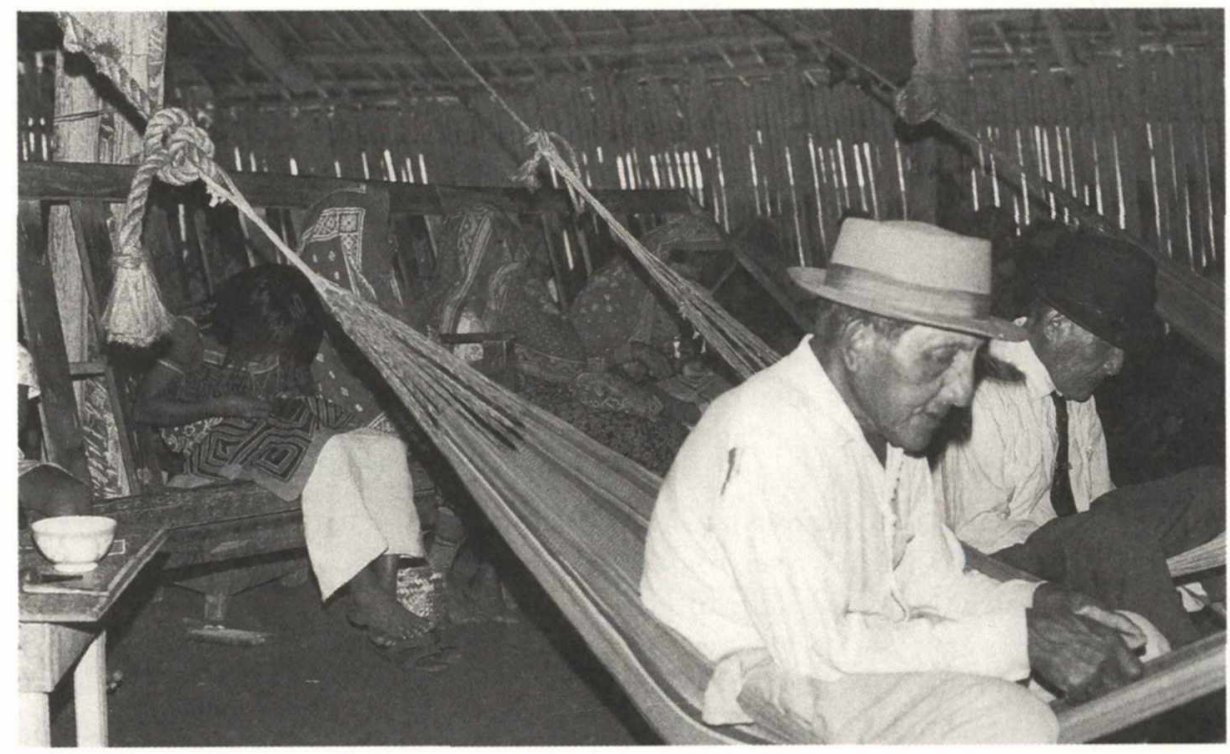

Foto af forfatteren

\section{Arkan kae som model for kommunikation}

Arkan kae-modellen for ceremoniel dialogisk hilsen ses også - om end i knap så udviklet eller struktureret form - mellem to venner eller familiemedlemmer, som ikke har set hinanden i lang tid, efterhånden som de aflægger beretning og fortæller hinanden om deres oplevelser i den periode, de har været adskilt. Modellen dukker sædvanligvis op i enhver form for samtale eller beretning.

Samtale i kunaforsamlingshuset er typisk struktureret som dialoger mellem to personer. Den talende er fortælleren, beretteren eller diskutanten, som rejser sig op for at tale og som regel bevæger sig fremad mod centrum af forsamlingshuset, idet han dog bliver ved den ydre omkreds af den inderste cirkel af høvdinge og talsmænd. Modtageren er en af forsamlingshusets funktionærer, enten landsbyens førsteh $\emptyset$ vding eller en anden høvding, en talsmand eller en anden leder, som har forestået den igangværende diskussion. De andre tilstedeværende i forsamlingshuset udgør publikum for denne konversation.

Den typiske kommunikationsstruktur i forsamlingshuset består således af tre deltagere: Den talende, modtager-svareren og publikum. Denne formaliserede og ritualise- 
rede struktur kanaliserer følelsesudbrud og konflikter gennem landsbylederskabet. Der fokuseres på kontrolleret veltalenhed og retorik snarere end på direkte udtryk for vrede mod en anden person; man underkaster sig ikke autoriteterne eller de politiske landsbyledere per se, men udviser derimod agtelse for evnen til kommunikation og kompromis. Kunaerne, som er sig fuldt bevidste, at deres verden er fuld af jalousi, vrede og mistillid, ønsker udadtil at fremtræde som et kooperativt og harmonisk samfund - deres konversationsstruktur med tre deltagere udgør midlet til at kanalisere offentlig tale over i en harmonisk form.

Hverdagskonversationer har ikke en lige så stramt formaliseret struktur som begivenheder i forsamlingshuset, men strukturen med to eller tre deltagere er temmelig almindelig. To personer, som ikke har set hinanden i nogen tid, eller som har vigtige personlige anliggender at drøfte med hinanden, gør det i en ritualiseret form; ofte foregår det inde i den enes hus, og ofte sidder eller ligger de i hver sin hængekøje. Typisk er det den ene, der taler, linje for linje, mens den anden svarer med tekii (sådan er det), lyden aa eller mm eller et grynt. Efter en serie af sådanne replikker og svar, bytter de roller som taler og svarer. Dette mønster ligger midt imellem den stærkt ritualiserede forsamlingshussang som for eksempel arkan kae på den ene side, og mere spontane og uformelle verbale udvekslinger på den anden. Også i sidstnævnte dukker strukturen med to eller tre deltagere ofte op; uformel snak inden for en gruppe mennesker organiseres hyppigt på en sådan måde, at to personer fører en dialog, som de andre overværer og kommenterer nærmest som et publikum og ikke som direkte modtagere. Beretninger om personlige oplevelser eller nyheder følger typisk dette mønster.

I daglig samtale ses den ceremonielle dialogform tydeligst i bestemte situationer og specielle rolleforhold. Nære venner, som ser hinanden hver dag, samtaler ofte på det samme sted, enten alene eller med andre til stede. To mænd, der har et særligt indbyrdes forhold, som for eksempel far og søn, svigerfar og svigersøn eller lærer og elev, taler sammen i form af en ritualiseret dialog. Ligeledes samtaler vært og gæst i denne form inden for hjemmet. Gæsten, der ofte har nogle oplevelser eller nyheder at berette, sætter sig først og bydes på noget at drikke. Når gæsten er færdig med at drikke, taler han eller hun med lederen af husholdet, en ven eller en slægtning, og andre lytter og kommenterer. Men det er klart, at de centrale, primære deltagere i samtalen er gæsten og lederen af husholdet, og at de andre tilstedeværende hovedsageligt er publikum eller tilskuere. Den samme konversationelle struktur bruges blandt medlemmer af et enkelt hushold, mand og kone, far og søn, mor og datter, bror og bror, når den ene af parterne har noget at berette. Jo mere betydningsfulde nyhederne er, jo mere potentielt konfliktfyldt beretningen er, des mere sandsynligt er det, at denne struktur med to eller tre deltagere vil blive anvendt til at kanalisere talen over i en form, hvori udtryksmåden kontrolleres omhyggeligt, og talen kan flyde harmonisk, på samme måde som det sker i forsamlingshusdiskursen.

\section{Kunas hilsner}

Det vil her være formålstjenligt at placere arkan kae inden for rammerne af kunahilsner mere generelt. De korteste hilseformer, verbale og nonverbale, bruges mellem to personer, som i et lokalsamfund ser hinanden regelmæssigt, når disse passerer hinanden, eller når de skal foretage sig noget sammen. Der er visse tidspunkter på dagen, specielt tidligt 
om morgenen, når folk tager af sted på arbejde, eller om eftermiddagen, når de vender hjem, hvor luften konstant genlyder af pia pa nae?, ,hvor skal du hen?“, og pia pe tanik$k i$ ?, ,hvor kommer du fra?“", to meget almindelige hilsner. Hilsner er ikke obligatoriske, undtagen i junglen på fastlandet, hvor der, ud over tekitte, ,nå men hej“, og anna og na, der begge betyder sådan noget som ,hej“, udveksles spørgsmål og svar mellem de enkelte omkring deres aktiviteter.

Mere omfattende hilsehandlinger bruges af personer fra det samme lokalsamfund, som står i et nært socialt forhold, det være sig slægt- eller venskab, og som har været adskilt i nogen tid; mennesker fra forskellige lokalsamfund, der besøger hinanden; eller to høvdinge fra forskellige landsbyer på officielt, rituelt besøg, i hvilket tilfælde hilsnen er en offentlig arkan kae. Arkan kae er den eneste af kunaernes mange former for hilsner, der findes et egentligt navn for. Der findes ikke noget kunaord for hilsen i al almindelighed. Håndtryk bruges kun mellem mænd efter en længere adskillelse, og de er stort set begrænset til landsbyfunktionærer. To høvdinge, den syngende og svareren, giver somme tider hinanden hånden umiddelbart før, de begynder at synge om aftenen.

Når to nære venner eller familiemedlemmer ikke har set hinanden gennem længere tid, fordi den ene af parterne har tilbragt adskillige måneder eller år uden for landsbyen, synes de to til tider at undgå hinanden og ikke udveksle nogen åbenlys hilsen overhovedet. Alligevel er de i stand til være på det samme sted på samme tid, det være sig på landingsbanen, ved anløbsbroen eller i forsamlingshuset. Hver især er de sig tydeligvis den andens tilstedeværelse bevidst. Den slags undgåelse er meget markant blandt de sædvanligvis snakkesalige kunaer. Den person, som blev hjemme, udfører ikke øjeblikkets normale aktiviteter - jagt, markarbejde, fiskeri, medicinindsamling, tøjvask eller madlavning - men sørger derimod omhyggeligt for at være på den tilbagevendendes ankomststed. Der er også andre til stede, så der kan godt forekomme en masse snak, men de to personer interagerer ikke direkte med hinanden. Senere, i et af hjemmene, når de ligger ved siden af hinanden eller sidder i hængekøjer ved siden af hinanden, vil de to hilse verbalt på hinanden, spørge og svare på en serie af spørgsmål om rejser, aktiviteter og helbred, et mønster som i høj grad ligner den arkan kae, som høvdingene fremfører.

Dette mønster, hvor to personer tilsyneladende undgår hinanden, ligner i nogle henseender den kommunikative stilhed, som er blevet beskrevet for visse nordamerikanske indianergrupper. For kunaernes vedkommende bør denne tilsyneladende undgåelse, som i realiteten er en gensidigt anerkendt fælles tilstedeværelse, ikke ses som et fravær af hilsen, men derimod som en udspænding og trækken i langdrag af den samlede hilseproces, hvis første del er nonverbal. Denne udstrækning af hilseprocessen forudsætter samarbejde og reflekterer en mere generel regel, nemlig, at jo mere specielt og betydningsfuldt det sociale forhold mellem personerne er, des større er den grad af interaktion, der er nødvendig for at markere og genskabe dette forhold i hilsner (se Goffman 1971). Således forlænger nære venner og familiemedlemmer hilseprocessen ved at kombinere offentlig nonverbal, gensidigt anerkendt fælles tilstedeværelse med senere privat udspørgen og svaren. Og to høvdinge, de politiske og rituelle ledere for to forskellige lokalsamfund, forlænger hilseprocessen ved at synge en langvarig og offentlig rituel hilsen på et esoterisk sprog (arkan kae).

Arkan kae står dermed i skæringspunktet mellem tre kategorier eller typer inden for kunaernes samtaleformer: Forsamlingshusbegivenheder, hvoraf den er den mest rituelle og ceremonielle; hilsebegivenheder mellem to personer, hvoraf den er den mest speciel- 
le, udviklede og rituelle, og daglig samtale og anden verbal interaktion, for hvilken den udgør en hyppigt forekommende model.

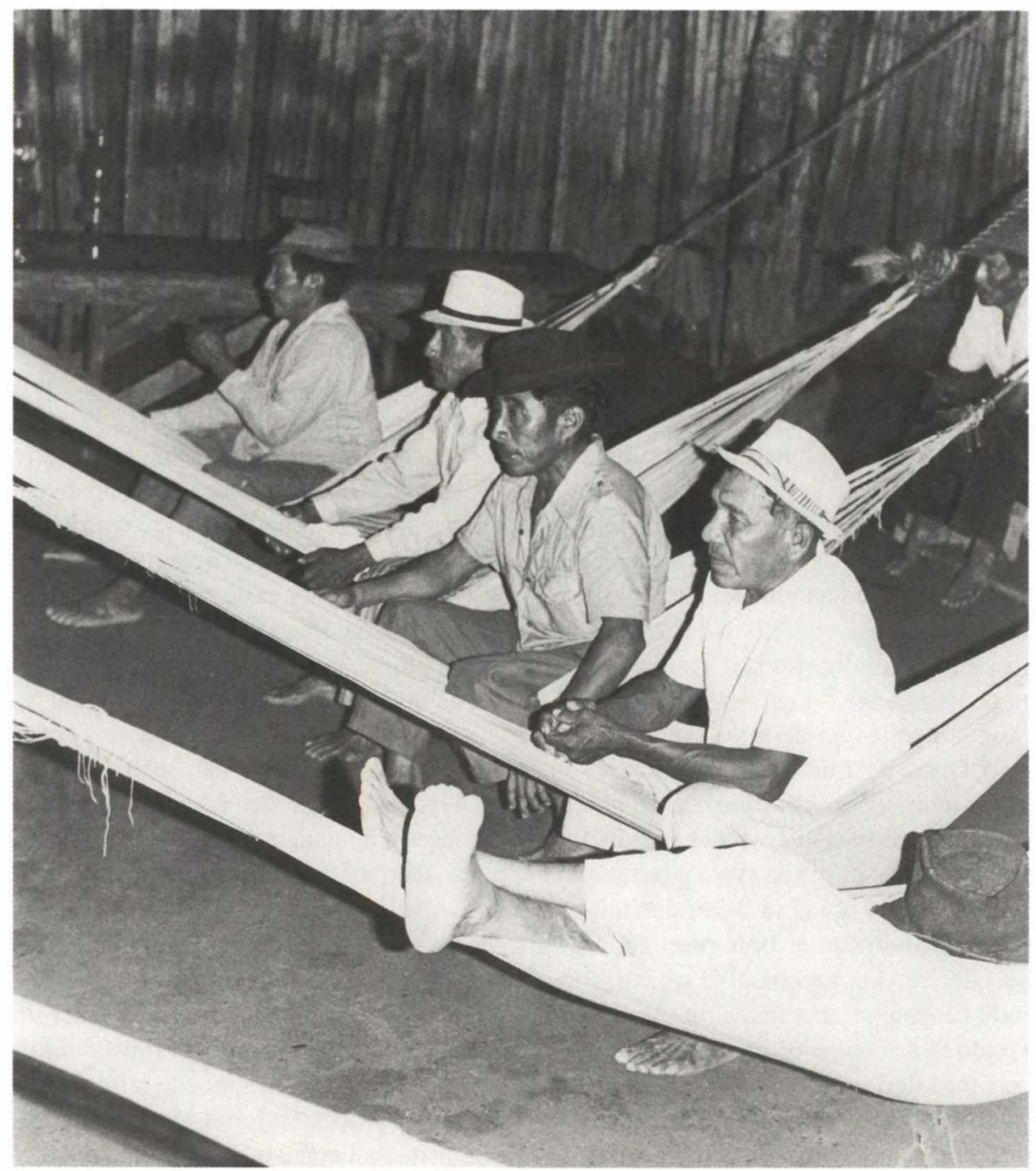

Foto af forfatteren

\section{Arkan kae: En repræsentativ illustration}

Den fremførelse af arkan kae, jeg præsenterer her, blev optaget 5. juli 1970 (jeg observerede og optog mange andre). De to deltagere var Høvding Mantiwekinya fra værtslandsbyen Mulatuppu og en besøgende høvding fra landsbyen Niatuppu. Niatuppu-høvdingen indledte begivenheden, mens Høvding Mantiwekinya var svareren. Det er denne del af begivenheden, jeg trækker på her. Den efterfulgtes af Mantiwekinya som taleren, og derefter endnu en ombytning af rollerne. 
Sangen begynder med en generel beskrivelse af høvdingens og hans landsbys helbred (vers 1-10). Dernæst følger den faktiske fortælling (vers 11-38). I versene 11-19 beskriver høvdingen mødet, hvorunder han indvilligede $\mathrm{i}$ at foretage turen, og hans forberedelser til turen. I vers 15 ændres den musikalske stil fra at være monoton hen imod det mere melodiske. Dette finder typisk sted ved begyndelsen til den fortællende del af høvdingens sang. I vers 20-26 beskriver høvdingen sin landsbys helbredstilstand ved at opremse de større sociale kategorier. Turen fra Niatuppu til Mulatuppu beskrives i vers 27-38.

Sangen er struktureret i vers, markeret af at svareren synger tekii, „sådan er det“. Hver høvding begynder at synge, når den andens sidste vokal dør hen, således at stemmerne overlapper, og der aldrig er stilhed. Versene består af en, to eller tre linjer, som alle bestemmes af en kombination af rammeord og vendinger (se nedenfor), samt faldende toneleje og lydstyrke.

Høvdingesang, arkan kae medregnet, karakteriseres af visse træk, der adskiller den fra hverdagstale, såvel som fra andre rituelle genrer for tale og sang. Morfemer og ord er længere end det typiske for hverdagstale, idet vokalendelser bibeholdes. For eksempel papa, snarere end pap, for „Fader“, neka, snarere end nek, for ,hus“ og yalakine, snarere end yarki, for ,på bjerget“". Eftersom arkan kae synges, indgår disse vokaler også i den melodiske udformning af fremførelsen.

Med hensyn til morfologi og syntaks gøres vendinger og sætninger mere komplicerede ved at tilføje verber som kue, ,gør, er“. Et eksempel er den tredje linje i vers 13, na pinsati kute, ,jeg tænkte, i sandhed, jeg med sikkerhed var“. Ligeledes i vers 24, linje 2: totokankarti wisi neka mai kue, „de små legesyge er en lille smule hjemme, er de“. Og i vers 33: inso teki na kalu par wimaytani kue, ,jeg er flyttet ud af mit tilflugtssted, er jeg“"

Fremførelsen er også udvidet, trukket i langdrag, og ofte struktureret ved hjælp af syntaktisk og semantisk parallelle linjer og vers. Et godt eksempel forekommer i vers 20 til 23, hvor helbredet hos de forskellige sociale kategorier af individer i høvdingens landsby beskrives. Et andet træk ved fremførelsen, der er karakteristisk for såvel kunahøvdingens sang som kunaernes tale mere generelt, er at aktørerne i fortællingen citeres ordret, som i vers $3,6,7,17,18,36$ og 37 .

$\mathrm{Al}$ kunatale er karakteriseret af en overdådighed af ord og fraser, som indrammer linjer og vers i fremførelsen. Dette er især tilfældet med høvdingens sang. Rammeskabende ord og vendinger er et vigtigt aspekt af poesien i denne genre, og nogle af dem er særegne for den. Eksempler er inso, ,,således“, taylekuti, ,,sandelig“, tayle, ,se“, teysokkuti, ,derfor" og oparye, „udtale“.

Visse morfemer og ord findes kun i høvdingens sang eller forekommer langt oftere $\mathrm{i}$ denne genre end i andre. Eksempler er $n a$, ,i sandhed“, og ye, ,sandsynligvis, forhåbentlig“. Tee har ingen direkte betydning, men forekommer ofte, måske både som en del af den melodiske rytme i sangen, såvel som en sproglig markør af denne genre.

Det mest karakteristiske og slående træk ved høvdingens sang, set fra et kunasynspunkt, er det figurative, poetiske og ofte esoteriske ordvalg, der anvendes. Medlemmer af publikum varierer med hensyn til deres evne til at forstå disse allusioner, der alle normalt udtrykkes på en mindre esoterisk måde i hverdagstale. Her er nogle eksempler: 
Arkan kae

poni, ,,ond ånd“ (vers 1 og andetsteds)

yala, ,bjerg“" (vers 3 og andetsteds)

kwennattikan upoketi, ,,brødre som

kom ind her" (vers 11)

kwake aipire, ,vende hjerte“ (vers 12)

pippirmakke, ,cirkulere omkring“(vers 13)

kwichi, ,rejse sig“ (vers 17)

kalu, ,tilflugssted“ (vers 19 og andetsteds)

pannakue, ,,adskille fra“" (vers 19 og 27)

tatamar yorukku, ,solen i midten“ (vers 27)

tuppu nasikke, „hængte øer“ (vers 28)

tiwar kammu, ,floders svælg“ (vers 29)

ata oakkute, ,solen forsvandt" (vers 31)
Hverdagstale

kekue, ,være syg"; weleke, ,have feber“

$n e k a$, ,verden“"

konkreso tratisional, ,rituel samling mellem

øerne indbyrdes"

pinsae, „tænke, beslutte“

nae, ,gå, forlade“; pasearsae, ,gå omkring “

soke onmakket nekki, ,sige, kundgøre i forsam-

lingshuset"

nekkwepur, ,landsby“

nae, ,gå, forlade“"

yorukku, ,middag“; wachi ilambeki;

kakka pokwa, ,klokken tolv“"

tuppu opeke, ,forlade/afgive øer“

tiwar, ,flod“"

tat arkwatte, ,solnedgang“

Figurativ tale bruges ofte til at repræsentere forskellige sociale kategorier og grupper inden for kunasamfundet. Således:

kwennatti, ,brødre“ (vers 11 og andetsteds)

suar ipet, ,ejer af stokken“ (vers 22)

amulu, ,tanter“" (vers 23)

totokana, ,de legesyge“ (vers 24)

tatakana, ,bedstefædre“ (vers 25) kunafolk, især mænd, generelt

kunaernes landsbybetjente

kun kvinder generelt

små børn

gamle mennesker

Høvdingesang, arkan kae medregnet, gør brug af mange fælles udtryk, konventionelle temaer eller topoi. Ud over at være forventede elementer i teksten tjener disse, i lighed med syntaktiske og semantiske paralleliseringer, som hjælp for hukommelsen og letter en flydende fremførelse. De giver også levende beskrivelser af faktiske begivenheder, folk og steder, og bibringer teksten en æstetisk skønhed. Eksempler fra teksten, som præsenteres her, er: Fader, som har efterladt de onde ånder (vers 1 og 3-7); høvdingen og hans landsby, som har gennemlevet nogle dårlige (syge) dage og måneder (vers 2, 8, 9); kundgørelsen i forsamlingshuset af den rituelle samling fælles for flere øer (vers 11, 12, 17); en beskrivelse af helbredstilstanden hos landsbylederne og andre medlemmer i lokalsamfundet (vers 20-25); høvdingen, der ser øerne og floderne, mens han rejser forbi (vers 28-29) og fastslår, at Fader (Gud) har udformet dele af naturen, for eksempel havets bølger, som høvdingen ser på sin færd (vers 30).

\section{Afslutning}

I lyset af det arbejde Fock og andre, der fulgte efter ham, har udført, bør det afslutningsvis pointeres, at den ceremonielle dialogiske model for tale, som er vidt udbredt i oprindelige, oralt baserede samfund i Latinamerika - såvel en model af som en model for verbal praksis (i Clifford Geertz' betydning) - gradvist, men til tider brutalt erstattes med en anden model, hvormed den længe har været i konkurrence og konflikt; den i Europa udsprungne, monologiske og skriftbaserede model (se Sammons \& Sherzer under udgivelse, især Gnerres artikel). ${ }^{2}$ 


\section{Arkan kae - kuna}

inso papati poni pulekana.

anka ipakampa pukki.

neka pule tayle tee oparye.

tekii

teki ipa iskanapi.

niulu okkwinmayte teyye.

anka tuppu neka kue tee oparye.

tekii

inso papati maka soysa tayle.

,mimmimarye we yalakine.

na peka poni tulekan urpe" tee oparye.

tekii

inso taylekutina.

papa tummati te yala pillikampa.

pela poni kammukampi teye.

papa namneka epechunna tee oparye.

tekii

inso papati taylekuti.

poni yala sipepkampi tayle.

poni soypekampi papa namneka epeyee.

tekii

„teysokkuti pani we yalaki tayle.

pani sana suirmakkakwale nanaosurye".

papa soysa nachun tee oparye.

tekii

,inso ipakampa tayle.

pani poni kakka kapyalati pani nanato“ tee oparye.

tekii

inso teesikki tayle.

ipa pulekampi na nasikke maikus tee oparye.

tekii

inso niulu pulekampi.

na okwamai kwar tee oparye.

tekii

inso tee yopi tayle.

anka nekati kue tee oparye.

tekii

teysokkuti taylekuti.

we sikki taylekuti kwennattikan upoketii.

na wiskuali tayle tee oparye.

tekii

inso teki sokkuti.

\section{Arkan kae - oversættelse}

Således [efterlod] Fader stærke onde ånder [sygdomme].

Blandt os en dag.

Jeg ville være ked af at møde dem, udtales det.

Sådan er det.

Altså nogle dårlige dage.

Og nogle dårlige måneder, som vi afsluttede godt.

På mit østed [landsby] har vi, udtales det.

Sådan er det.

Således som Fader sagde, se.

„Børn på dette bjerg [verden].

I sandhed har jeg efterladt onde åndemennesker [sygdomme] for jer at se", udtales det.

Sådan er det.

Således sandelig.

Store Fader, se, i bjergets lag [verden].

Alle høvdingene af de onde ånder, se.

Fader drog af sted mod det jordiske sted [verden], udtales det.

Sådan er det.

5 Således sandelig Fader.

Onde ånder, små bjergdyr [som spiser kokosnødder], se.

Mange slags onde ånder Fader efterlod i denne verden.

Sådan er det.

„Derfor I på dette bjerg [verden], se.

Ivil ikke gå med jeres kroppe rene [uden sygdom]“.

Fader sagde, og drog af sted, udtales det.

Sådan er det.

„Således i jeres dage, se.

I vil gå omkring blandt de onde ånder", se, udtales det.

Sådan er det.

Således der, se.

Jeg tilbragte nogle stærke [dårlige] dage, se, udtales det.

Sådan er det.

Således nogle stærke [dårlige] måneder.

Jeg er i færd med at forandres [slutte], jeg er, udtales det.

Sådan er det.

Således som dette, se.

10 Det sker for mig i mit land, det gør, se, udtales det.

Sådan er det.

Derfor sandelig,

Af de brødre, sandelig, som kom ind her [fordi der skulle være en rituel samling imellem øsamfundene indbyrdes].

Jeg lærte, i sandhed, se, udtales det.

Sådan er det.

Således derfor. 
teesikki na kwake aipilis ittole.

neka kute tayle tee oparye.

tekii

inso aya nuekan aparki.

na pippirmayti na samalar kepo tayle teyee.

na pinsati kute sun tee oparyee.

tekii

inso teki kutayle.

napir ittoletako inso tayle tee oparye.

tekii

teki tayle.

teki an tummakana pete tee oparye.

tekii

teki kino tayle teye.

uluse marko ipi soke tayle tee oparye.

tekii

inso tekirti ,ani kwatti“ na kwichikuchunno teye.

naka sortamarka ipi soyna tee oparye.

tekii

inso „napirye" soke tayle.

ipti kue tayle tee oparye.

tekii

emite teki kaluki tayle.

an tummakana epete na pannakuarteye oparye.

tekii

inso pela nuekampimar tayle.

an tummakan anka kue tee oparye.

tekii

inso taylekuti an arkarmala nuekampi.

anka neka kue tee oparye.

tekii

inso pela an suar ipekana nuekampi teye.

neyti kue tayle tee oparye.

tekii

inso taylekuti anti amulu nuekampi teye.

ikar susimo an nuekampi antu kue tee oparye. tekii

inso tayle sikwa sikwa tayle.

totokankarti wisi neka mai kue tee oparyee.

tekii

inso tatakante na takke kuu.

ooka ani sana oelemalo tee oparye. tekii

inso tayle neka akkarsulimo tayle teye.

ipti kue tayle tee oparye.

tekii
I sandhed vendte jeg mit hjerte [besluttede], det bliver hørt.

At deltage, se, udtales det.

Sådan er det.

Således blandt gode venner.

Jeg vil i sandhed cirkulere omkring da, se.

Jeg tænkte, i sandhed, jeg med sikkerhed var, udtales det.

Sådan er det.

Således godt det var, se.

Jeg ville føle godt [ved at tage af sted], således se, udtales det.

Sådan er det.

Altså, se.

15 Altså, jeg forlod mine foresatte, udtales det.

Sådan er det.

Altså, jeg var parat til at tage af sted, se.

Jeg gik ombord på båden, det er det som siges, se, udtales det.

Sådan er det.

Således altså, ,Jeg selv“ [ [vil drage af sted], jeg rejste mig [sagde], se.

Det er, hvad jeg sagde til mit følge, se, udtales det. Sådan er det.

Således ,det er godt“, sagde de, se.

Det er hvad der skete, se, udtales det.

Sådan er det.

Nu altså i mit tilflugtssted [landsby], se.

Jeg drog af sted, og i sandhed adskilte jeg mig fra mine foresatte, udtales det.

Sådan er det.

Således, alle er ved godt helbred, se.

20 Mine foresatte er, se, udtales det.

Sådan er det.

Således, sandelig mine talsmænd er ved godt helbred.

I min landsby er de, udtales det.

Sådan er det.

Således, alle mine ejere af stokkene [landsbybetjente] er ved godt helbred.

Det er sådan landsbyen er, se, udtales det.

Sådan er det.

Således, sandelig, mine tanter [landsbyens kvinder] er ved godt helbred.

På mit sted er det sådan, det er, udtales det.

Sådan er det.

Således, se, lidt her og lidt der, se.

De små legesyge [børn] er en lille smule hjemme

[syge], er de, udtales det.

Sådan er det.

Således, se bedstefædrene, i sandhed, se

Mine lider af forkølelse, udtales det.

25 Sådan er det.

Således, se, der er ikke andre problemer, udtales det.

Sådan er det. 
emite taylekutina.

tatamar yorukkuttipar na pannakuar niatup kalukin tee oparye.

\section{tekii}

inso papati taylekuti.

tuppumala nasiysa tayle.

teepi na partaytani tee oparye.

tekii

papati taylekutina.

kwenattikana tiwar kammu yote tepi na palopetani tee oparye.

tekii

inso papa tummatitina.

aukka pillikana makkite kwatti pina partaytani

ku tee oparye.

tekii

inso tata ulu oakkute tayle.

ailikanti nappase par opunnote tayle tee oparyee.

tekii

teki na taylekuti.

na par oipoar ittole kine taylearpar tee oparye.

tekii

inso teki na kalu pa wimaytani kue tee oparye.

tekii

teki sikwa sikwa ulu anka nakutani tayle.

neyti kue tayle tee oparye.

tekii

inso tayle mar ulu ikinnali.

we kaluse tayle tee oparye.

tekii

emite ulu kaptanna te anka soke tee.

„weki opunno te paneki nao“ tee oparye.

tekii

inso ,napir moye“ na ka soke tayle tee oparye.

tekii

inso te yopi ipi kue tayle tee oparye tee.

tekii

inso te yopi.

soke tayle pitto.

Chief Mantiwekinya says: teina pe itto moka.
Nu, sandelig.

Da solen i midten var [middag], drog jeg, i sandhed, af sted fra mit tilflugtssted [landsby] Niatup, udtales det.

Sådan er det.

Således, Fader, sandelig.

Hængte [forlod] mange øer, se.

Altså, i sandhed, jeg så dem, da jeg kom, udtales det.

Sådan er det.

Fader, sandelig.

Forlod mange floders svælg [floder] for vore brødres [kunafolkets] skyld, altså, og jeg så dem, efterhånden som jeg kom frem, badede i dem, udtales det.

\section{Sådan er det.}

Og således, Store Fader.

30 Formede de mægtige havets bølger, og jeg så dem også, da jeg kom, udtales det.

Sådan er det.

Således, solen forsvandt [gik ned], se.

$\mathrm{Og}$ jeg hvilede mig ved Ailikantis jord [landsby], se, udtales det.

Sådan er det.

Altså, i sandhed, sandelig.

I sandhed, ved daggry, høres det, var jeg parat og fortsatte med den, udtales det.

Sådan er det.

Således, altså, jeg er i sandhed flyttet ud af mit tilflugtssted [landsby], er jeg, udtales det.

Sådan er det.

Altså, lidt efter lidt kom jeg og lagde båden til kaj, se.

I hver landsby gjorde jeg, se, udtales det.

Sådan er det.

Således, se, torden brølede.

35 Mens vi ankom til det tilflugtssted [landsby], se, udtales det.

Sådan er det.

$\mathrm{Nu}$ sagde bådens kaptajn til mig.

„Her vil vi hvile os, og i morgen vil vi fortsætte“, udtales det.

Sådan er det.

Således, ,det er også godt", sagde jeg, i sandhed, til ham, se, udtales det.

Sådan er det.

Således, det er præcis sådan, det har været, se, udtales det.

Sådan er det.

Således, nøjagtig sådan.

Jeg siger, hørte I det.

Høvding Mantiwekinya siger: Altså, i sandhed, jeg hører også jer. 


\section{Noter}

1. Forskningen bag denne artikel blev udført i San Blas, Panama, hovedsagelig på øen Mulatuppu, i en serie af besøg mellem 1968 og 1997. Denne forskning blev støttet af University of Texas, National Science Foundation, National Institute of Mental Health og John Simon Guggenheim Memorial Foundation.

2. Ved den faktiske fremførelse af helbredelsesritualet er det dog kun den ene side af denne dialog, nemlig den menneskelige, der høres (o.a.).

\section{Litteratur}

Burns, Allan F.

1980 Interactive Features in Yucatec Mayan Narratives. Language in Society 9:307-19.

Fock, Niels

1963 Waiwai: Religion and Society of an Amazonian Tribe. Copenhagen: National Museum.

Geertz, Clifford

1973 The Interpretation of Cultures. New York: Basic Books.

Goffman, Erving

1971 Relations in Public. New York: Basic Books.

Sammons, Kay and Joel Sherzer (eds.)

n.d. Translating Native Latin American Verbal Art: Ethnopoetics and Ethnography of Speaking.

Washington D.C.: Smithsonian Institution Press. (Under udgivelse).

Sherzer, Joel

1983 Kuna Ways of Speaking: An Ethnographic Perspective. Austin: University of Texas Press.

1990 Verbal Art in San Blas: Kuna Culture through its Discourse. Cambridge: Cambridge

University Press.

Sherzer, Joel and Greg Urban (eds.)

1986 Native South American Discourse. Berlin: Mouton Publishers.

Urban, Greg

1986 Ceremonial Dialogues in South America. American Anthropologist 88: 371-86. 